\title{
NON-FINANGIAL REPORTING AND REPUTATIONAL RISK IN THE ROMANIAN FINANCIAL SECTOR
}

\author{
Laurențiu Tăchiciu ${ }^{1 *}$, Melinda Timea Fülöp ${ }^{2}$, Andreea Marin-Pantelescu ${ }^{3}$, \\ Ionica Oncioiu ${ }^{4}$ and Dan Ioan Topor ${ }^{5}$ \\ 1) 3) The Bucharest University of Economic Studies, Romania \\ ${ }^{2)}$ Babeș-Bolyai University, Cluj-Napoca, Romania \\ 4) Titu Maiorescu University, Bucharest, Romania \\ 5) “1 Decembrie 1918” University of Alba Iulia, Alba-Iulia, Romania
}

\section{Please cite this article as:}

Tăchiciu, L., Fülöp, M.T., Marin-Pantelescu, A., Oncioiu, I. and Topor, D.I., 2020. Non-Financial Reporting and Reputational Risk in the Romanian Financial Sector. Amfiteatru Economic, 22(55), pp. 668-691.

\section{Article History}

Received: 30 March 2020

Revised: 9 May 2020

Accepted: 27 May 2020

DOI: $10.24818 / \mathrm{EA} / 2020 / 55 / 668$

\begin{abstract}
Good reputation is an important intangible asset for any company, but it can be vital for financial institutions. Today, given that the demands on the business environment in terms of social responsibility have greatly increased, the reputation can be worn not only by serious events, but also by the omission or delay of possible and necessary measures and actions to strengthen the sustainability of the activity. In this context, it turned out that there is a strong connection between reputational risk management and the public disclosure of information on the social and environmental impact of the company's activities. This paper proposes a contribution to the empirical decoding of this inter-conditioning through a two-pronged research: on one hand, it investigates the way in which Romanian banking institutions treat reputational risk management and, on the other hand, it analyzes the content of non-financial reports of some financial institutions in the light of the maturity with which they deal with sustainability. The resulting information suggests that there is a delay in understanding the significance of reputational risk and a decoupling of corporate responsibility policies from the risks associated with the business model.
\end{abstract}

Keywords: reputational risk, social responsibility, non-financial reporting, financial sector

JEL Classification: G21, M14

* Corresponding author, Laurențiu Tăchiciu - laurentiu.tachiciu@gmail.com 


\section{Introduction}

Over the last decade, the financial sector has faced complex challenges and growing pressures. Traditional financial sector institutions, especially banks, must respond to the threat of alternative solutions based on new information and communication technologies and, at the same time, refresh their legitimacy as a key pillar of sustainable economic development. In this context, (i) reputation management and (ii) effective communication of social responsibility policies are of particular importance. The two issues also become more stringent due to the regulation of the obligation to publish non-financial information, the socalled non-financial reporting (NFR). This paper presents the results of exploratory research conducted in order to know the concrete way in which the institutions of the financial sector in Romania manage, on the one hand the reputational risk and, on the other hand, the NFR. Empirical observations are analyzed and discussed in light of the literature and the desired outcomes, as stated in official documents. At the same time, the interdependencies between reputational risk management and genuinely socially responsible corporate conduct are highlighted.

The paper firstly presents the context of concerns about the reputation and accountability of financial sector institutions, followed by a review of the literature on reputational risk and non-financial reporting. The third section presents the results of a questionnaire-based survey on the extent to which financial sector institutions in Romania manage reputational risk and the fourth section presents findings from the NFR of the most important banks in Romania analysis. Finally, the authors' conclusions are summarized.

\section{Context}

In his inaugural address to the White House, the former US President Barack Obama said: "Our economy is severely weakened, a consequence of greed and irresponsibility on the part of some, but also of our collective failure to make difficult choices and to prepare the nation for a new era. ... What we are being asked to do now is a new era of responsibility ...." (Obama, 2009). Indeed, the global financial crisis has highlighted the weaknesses of the banking financial system, shaken the economy, shattered public confidence and led politicians to respond with coercive measures aimed essentially at: increasing the resilience of financial institutions to adverse developments through capital adequacy and liquidity reserves, the creation of a bankruptcy bailout system that avoids significant costs for the economy and taxpayers, the imposition of high requirements for transparency. Internationally, the measures were largely coordinated by the Basel Committee on Banking Supervision (BCBS). At the-European Union level, Directive (36/2013 amended by $878 / 2019$ ) regulated the access to the activity of credit institutions and the prudential supervision of credit institutions and investment firms. Based on the costly lessons of the financial crisis, the intervention targeted two plans:

- short-term restoration of the stability of the financial system through stricter prudential rules which the institutions concerned are required to apply and through a more vigilant supervisory system, on the one hand, and

- a profound reform of the financial system and its transformation from a system designed to serve selfish interests into a secure and effective system for supporting sustainable economic and social development, on the other hand. 
As vectors for a fundamental transformation, they rely on:

- a much more comprehensive definition of risks;

- increasing transparency;

- increasing responsibility;

- reduction of incentives for taking risks.

For example, the corporate governance principles developed for CBSB banks (2015, p.27) include the following wording: "Risk identification and measurement should include both quantitative and qualitative elements. Risk measures should also include a qualitative perspective on the risk to the bank as a whole, in relation to the bank's external operating environment. At the same time, banks should consider and assess risks that are more difficult to quantify, such as reputational risk". Special attention is required to qualitative risks, the external environment of the bank is evoked and reputational risk is mentioned, all of which illustrate a new approach compared to previous editions.

In the same spirit, the European Union supplemented Article 98 of Directive 36/2013 to entrust the European Banking Authority (EBA) with the task of making proposals on the inclusion of Environmental, Social and Governance (ESG) risks among the supervision criteria of financial institutions. In fulfilling its mandate, the EBA recently published the Sustainable Financial Sector Action Plan (EBA, 2019) emphasizing the need to accelerate the expected regulations in the field, as well as the need for financial institutions to act proactively, inter alia on the basis of Directive 95 / 2014.

EU Directive 95/2014 regulates the obligation of large companies and groups, which are of legitimate concern to the public due to the potential economic and social impact of their activity, to make public a range of non-financial and information about diversity. Credit and insurance institutions are explicitly indicated among the entities covered by the Directive. This obligation of "non-financial reporting" (NFR) was transposed in Romania by the Order of the Minister of Finance no. 1938/2016 of 17 August 2016, with application from 2018.

Entities covered by the Directive are required to provide information on at least environmental, social and personnel issues, respect for human rights, the fight against corruption and bribery. The NFR must contain: 1) a description of the company's business model; 2) description of the policies adopted by the company in connection with the mentioned aspects; 3 ) the main risks associated with the mentioned aspects arising from the company's operations; 4) key indicators of non-financial performance relevant to the specific activity of the company.

Pending unitary NFR standards at European level, the concerned entities are encouraged to adopt a reporting structure that reflects key issues and risks specific to their own business model. It tests the readiness of those institutions to deal openly with less favorable realities.

In addition to recognizing the vital role of the financial sector in achieving the goals of sustainable development, the developments described in this section are also an expression of a lack of confidence in the social responsibility of entities that make up the sector. The credibility of the entire financial sector has been severely affected by the irregularities revealed by the global financial crisis. It calls into question a discretionary attitude of financial sector institutions towards society as a whole, in contrast to the obligation to ensure - for the benefit of society - a responsible and efficient management of financial resources. 
This largely hostile public sentiment has a stronger and more lasting impact on financial institutions - even at the local and even individual level - compared to certain concrete scandalous events.

In Romania, credit and insurance institutions have been the target of attacks by opinion leaders and political leaders several times in the last decade. These were: the case of loans in $\mathrm{CHF}$ amid the sharp rise in the exchange rate of the Swiss franc against the main currencies, the case of automotive third party liability insurance, the case of pension fund administrators in Pillar II, allegations of bank manipulation of interbank interest rates. Even though the attacks had a populist note on the background of poor financial education, the financial system always seemed unprepared and even unwilling to work to clarify things, fix problems, regain confidence, defend and strengthen its reputation. The Romanian Association of Banks speaks in a low tone about the need to restore trust between the financial system and society, but does not say what banks and other institutions of the financial system must do to regain credibility.

It is clear that the financial sector has a long and difficult road ahead to gain new legitimacy in relation to the aspirations of the contemporary economy and society. Financial institutions - and in particular banks - need to move beyond the current phase of victimization and compliance with externally imposed laws, regulations and standards. It is time for them to take a pro-active stance based on understanding and voluntarily taking on their responsibilities to the economy and society. A test in this regard can also be the way they look at reputational risk management in conjunction with the responsibility and good governance policies that are the subject of NFR.

\section{Strengthened reputational risk management and increased transparency on non-financial issues - indicators of progress towards a sustainable financial sector}

Reputational risk management is increasingly discussed in the literature. Among the most influential authors there are (Walker, 2010; Carreras, et al., 2013; Sarstedt, et al., 2013; Gatzert, 2015). The question arises: Is it possible to manage the risk related to the company's reputation in the same way as we manage credit or other risks within financial institutions? Also, can we teach employees of financial institutions to respect work ethic?

The EY (Global Banking Outlook, 2017) survey of executives from nearly 300 banks in Europe, America, Africa and Asia-Pacific shows that reputational risk management is a priority for $69 \%$ of banks, and improving cybersecurity and Data security is on the agenda of $64 \%$ of these banks

It is very important for companies to pay more attention to the elements that influence reputation (Figure no. 1).

Reputational risk management is a key component of risk management for financial institutions. Thus, according to Carreras, et al. (2013): We are entering a new economic cycle that we can call the economy of intangible assets and corporate reputation. In this new context, the roles of companies and the traditional balance of power are changing. This means that power is transferred to stakeholders (public opinion, customers, employees, regulators, shareholders, suppliers) and their satisfaction (Radomir, et al., 2011), and the new role of companies and institutions is to be in the service of stakeholders. 


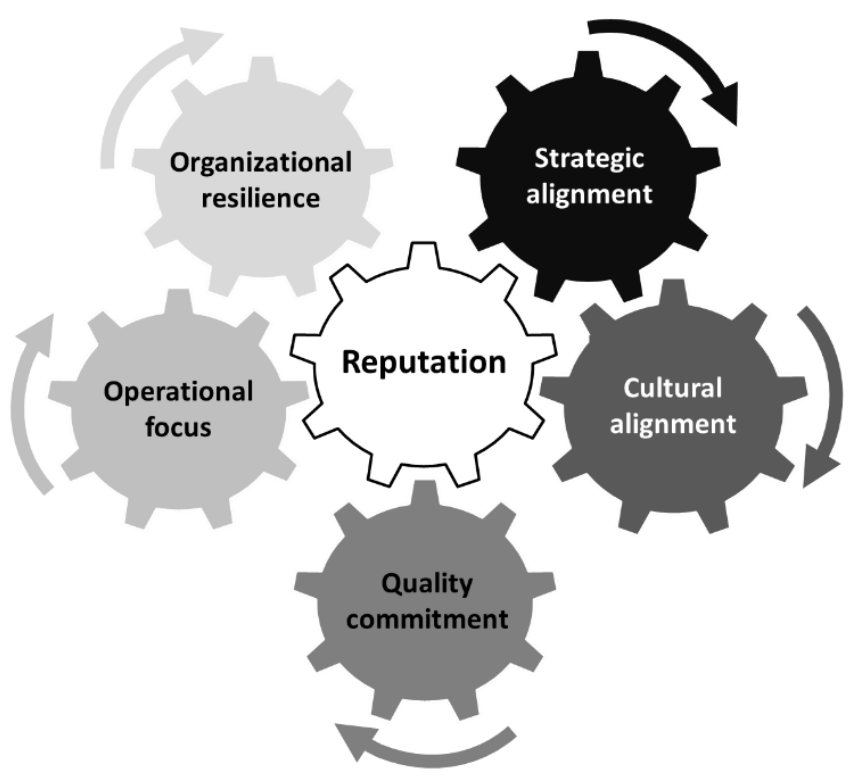

Figure no. 1. The elements that influence the reputation

According to Walter (2014), the reputational issue for financial services companies is more serious because financial services include "special" businesses. First, it deals with other people's money, and second, there are problems in financial intermediation that trigger external costs.

In order to be able to independently manage reputational risks, financial institutions must first distinguish them from other categories of financial or non-financial risks.

A synthesis of the interaction between the different types of risks within financial institutions is provided by Figure no. 2 .

Figure no. 2 suggests that reputation may be affected by the occurrence of any event associated with typical risks, those that are in the attention of financial institutions both by the nature of the business and by industry standards and regulatory and supervisory standards. However, reputational risk is a qualitatively different perspective. Four things must be stressed with strict reference to this figure:

- not all events associated with typical risks affect the reputation of a financial institution, but only those whose production or magnitude can be attributed to a lower performance in risk management than that considered normal for an institution in that class; normality in such a case it is not limited to compliance with the regulations but includes additional measures, recognized as common practice at the level of the industry concerned;

- reputational risk can also be interpreted as a multiplier of typical risks, in the sense that when an event associated with typical risks has an impact on the reputation there will be further consequences that will amplify the losses of the financial institution concerned; 
- reputation may be affected even in the absence of any direct short-term loss; in this case, the behavior of the financial institution contradicts the expectations of stakeholders; in this respect, things are complex: it may be general interests or different categories of interests that may be divergent, it may be a breach of promises (promises often made for propaganda purposes) or it may be an inability to reject unfounded allegations and denigrating attacks;

- damage to reputation leads to effects for the future; most often the effects are reflected in a loss of competitiveness (or competitive disadvantage) for the institution directly concerned, but - under certain conditions, to a greater or lesser extent - they can affect the whole industry.

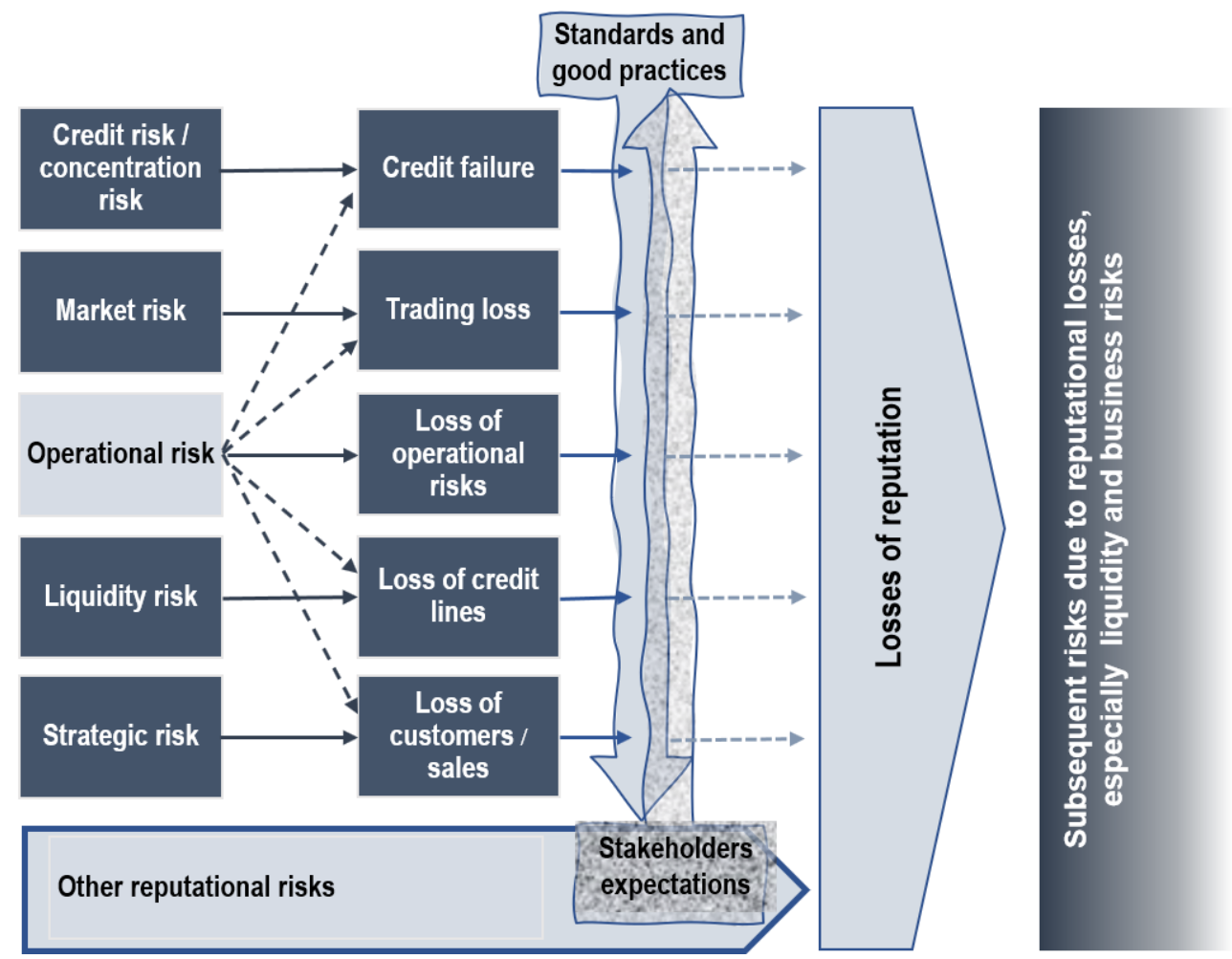

Figure no. 2. The interaction between reputational risks and other types of risks Source: Adapted by the authors after Kaiser (2010)

Corporate reputation is becoming increasingly important (Sarstedt, et al., 2013), and a positive corporate reputation can lead to a significant competitive advantage for firms (Gatzert, 2015). A good corporate reputation has positive effects on financial performance in general (Gatzert, 2015), and facilitates capital growth (Fombrun, et al., 2000). Along with the above there are several academic papers that have influenced the definitions of reputation and related key characteristics (Fombrun and Shanley, 1990; Fombrun and Van Riel, 1997; Bennett and Kottasz, 2000; Barnett, et al. 2006; Helm, et al. 2011; Barnett and Pollock, 2012; Rasheed, 2014; Gatzert, et al., 2016; Eckert, 2017). 
On the other hand, in the face of a more susceptible audience, intransigent opinion formers and a more incisive press, the corporate reputation becomes increasingly vulnerable (Larkin, 2003). Therefore, in addition to building a positive corporate reputation, protecting the reputation is crucial. Recognition of the growing importance of reputation for business stability and long-term success leads to an intensification of concerns for conceptualizing and substantiating reputational risk management models (Table no. 1).

\section{Table no. 1. Conceptual synthesis on reputational risk}

\begin{tabular}{|c|c|}
\hline $\begin{array}{l}\text { Board of Governor of } \\
\text { Federal Reserve System } \\
\text { (FED) (1995) }\end{array}$ & $\begin{array}{l}\text { Reputational risk is the potential by which negative publicity about an institution's } \\
\text { business practices, true or not, can cause a shrinking customer base, costly } \\
\text { litigation or revenue cuts. }\end{array}$ \\
\hline Fombrun (1996) & $\begin{array}{l}\text { Reputational risk is a perceptual representation of a company's past actions and } \\
\text { future prospects that describes the company's overall attractiveness to all of its } \\
\text { key components compared to other significant rivals. }\end{array}$ \\
\hline $\begin{array}{l}\text { Comitet Européen des } \\
\text { Assurances (CEA) } \\
\text { and Groupe Consultatif } \\
\text { Actuariel Europeen } \\
(2007)\end{array}$ & $\begin{array}{l}\text { Reputational risk is the loss of confidence in the integrity of the institution. } \\
\text { Reputational risk could result from other risks inherent in an organization's } \\
\text { activities. Risk of loss of confidence refers to stakeholders, which include, but are } \\
\text { not limited to, existing and potential customers, investors, suppliers and } \\
\text { supervisors. Therefore, in this definition, reputational damage consists of } \\
\text { impaired perceptions of stakeholders. }\end{array}$ \\
\hline Tonello (2007) & $\begin{array}{l}\text { Reputational risk represents the risk of a financial loss to the company caused by } \\
\text { a change in the behavior of the company's stakeholders, which in itself is caused } \\
\text { by the deterioration of the corporate reputation. }\end{array}$ \\
\hline Burkhardt (2008) & $\begin{array}{l}\text { Burkhardt (2008) defines reputation from an economic perspective as the sum of } \\
\text { the impressions that have emerged among all the interest groups of a company } \\
\text { based on past, present and future aspects. It is influenced by the experiences, } \\
\text { cognitive attitudes and requirements of the participants, based on which the future } \\
\text { behavior of a company and its impact on their own needs are assessed. }\end{array}$ \\
\hline $\begin{array}{l}\text { Basel Committee on } \\
\text { Banking Supervision } \\
(2009)\end{array}$ & $\begin{array}{l}\text { Reputational risk: "is the risk resulting from the negative perception of customers, } \\
\text { counterparties, shareholders, investors or regulating authorities that may } \\
\text { adversely affect a bank's ability to maintain its existence or establish new business } \\
\text { relationships and continuous access to financing sources". Reputational risk is } \\
\text { multidimensional and reflects the perception of other market participants. In } \\
\text { addition, it exists throughout the organization, and exposure to reputational risk } \\
\text { is a function of the adequacy of the bank's internal risk management processes, as } \\
\text { well as the manner and efficiency with which management responds to external } \\
\text { influences on bank-related transactions. }\end{array}$ \\
\hline Walker (2010) & $\begin{array}{l}\text { Reputational risk is a relatively stable, specific aggregate representation of the } \\
\text { company's past actions and future prospects, compared to a certain standard. }\end{array}$ \\
\hline $\begin{array}{l}\text { Federal Financial } \\
\text { Institutions Examination } \\
\text { Council (FFIEC) }(2010)\end{array}$ & Reputational risk is a financial loss caused by a damaged corporate reputation. \\
\hline Fombrun (2012) & $\begin{array}{l}\text { Reputational risk is a collective evaluation of a company attractiveness for a } \\
\text { specific group of stakeholders in report with a referential group of companies in } \\
\text { which the company compete for resources. }\end{array}$ \\
\hline
\end{tabular}

The most recent assessment of the reputation of corporations shows that ESG pillars have a $41 \%$ contribution to reputation building, but also the particularly relevant fact of increasing stakeholder demand for the authenticity of corporate commitments: "communicating about your business and what you are looking for in a genuine way" can bring a $4 \%$ improvement of your reputation (RepTrack, 2020, p.3) 
Reputational risk refers to the possibility that either the appreciation towards an organization or the trust towards it will suffer a negative impact. The distinction between appreciation and trust is particularly interesting for exploring the mechanisms of public perception and feeling. Although in 2019 the reputation of corporations has improved, the majority (54\%) of consumers are reluctant to show support for them (RepTrack, 2020). In other words, they will not give an organization the benefit of the doubt; in the event of information that would put it in a negative light.

Financial institutions that integrate reputational risk management at the heart of decisionmaking processes, understand sources of trust earlier, take a pro-active stance in favor of sustainable development, enjoy greater support from stakeholders, which gives them a competitive advantage in relation to their competitors.

In his analysis of the 2020 outlook for the financial sector, Deloitte (2020) notes that concerns about climate change and social impact will force banks to re-prioritize their role in society and sacrifice short-term gains for long-term sustainable development. Similarly, Ernst \& Young (2020) points out that, for the next decade, a major challenge for the financial sector is to "think differently about strengthening risk mitigation efforts, while preventing emerging threats, especially those that can lead to damage reputational or long-term financial penalties", given that, according to the same study, "the principles of responsibility come to the fore as investors want assurances that organizations are doing the right thing for customers and the planet". Therefore, reputational risk is involved not only in situations where financial sector institutions could do something wrong, with a negative impact on stakeholders, but also in situations where they neglect or delay to contribute to building a better future.

There is research and analysis on the reputational crises of financial institutions that have been generated by irresponsible managerial behavior or an extremely inefficient system of governance (Dowling, 2006). We can say - in agreement with CBSB (2010) - that corporate social responsibility is an important dimension and a reputational factor, because it positively affects the degree of transparency of information. Moreover, more and more researchers have recently focused on social responsibility within financial institutions by highlighting the complex relationships between responsibility and reputation (Eccles, et al., 2007; Plunus, et al., 2012, Weber, 2012; Wu and Shen, 2013; Thalassinos and Liapis, 2014; Perez and Rodríguez del Bosque, 2015; Jo, et al., 2015; Weber, et al., 2015; Suryanto, 2016; Forcadell and Aracil, 2017).

The analysis of the literature shows that:

- reputation becomes a decisive factor for the long-term stability and success of organizations, with even greater importance for the institutions of the financial system whose business is based on trust;

- institutions of the financial system need to place its reputation and associated risks at the heart of its decision-making mechanisms, by identifying broad stakeholder expectations, aligning strategies with higher-order goals, and preparing the organization to deliver on its commitments.

Transparency in environmental, social and governance policies is essential for reputation management and reputational risk mitigation. 
The relationship between social responsibility and reputation is unequivocal. Thus, a good reputation - as a factor of competitiveness - requires the display of responsible behavior. On the other hand, the responsible behavior includes an effective reputation monitoring system as a central element.

This is the crux of the problem that the authors of this article set out to investigate through a two-pronged approach:

- knowing the extent to which financial institutions in Romania recognize the importance of reputational risk and integrate its management into top decision-making processes;

- the analysis of the extent to which the non-financial information made public by Romanian financial institutions is convincing in order to assure stakeholders that the institution in question has understood its purpose and is doing the right thing, including maintaining a good reputation.

\section{Reputational risk management in the Romanian financial institutions}

Based on the literature, GRI standards and studies conducted by KPMG (2012) and AugeDickhut, et al. (2015), we conducted a questionnaire on reputational risk management in the Romanian financial institutions.

For data collection convenient sampling methods have been chosen (also known as availability sampling), which is a specific type of probability sampling method that is not based on collecting data from members of the population that are conveniently available to participate in the study. Thus, convenient sampling is a type of sampling in which the first available primary data source will be used for research without additional requirements. In other words, this method of sampling involves getting participants wherever we can find them and usually wherever convenient. In the convenient sampling no inclusion criteria were identified before the selection of subjects, all subjects are invited to participate.

Therefore, the questionnaire was sent to a selection of financial institutions in Romania (Annex 1). The questionnaire was addressed to the people involved in the management of the respective institutions, in order to acquire a better view on the situation. Following the survey, a number of 28 questionnaires were obtained and processed. Based on these answers, we performed a series of investigations, and in the following we will present the most relevant results.

The questionnaire used for data collection included invoice, knowledge and opinion questions with established answers to facilitate their processing and was written in Romanian. The questionnaire included questions on: the definition, structure and process of reputational risk within financial institutions. Thus, the questions focused concretely on the definition of the concept of reputational risk, where financial institutions had to choose from four predefined variants, one (a.) As an independent risk; (b.) As a consequence of a risk; (c.) As a cause of other risks respectively (d.) Cannot be explicitly defined.

Given the limiting conditions on the duration and type of information, the used questionnaire had a high degree of structuring, preferring closed questions, with simple and multiple choice. The information was processed based on the answers received, and their centralization was performed in relation to the concordance and convergence of the research objectives. 


\section{Results and discussions}

The correct definition and delimitation of the reputational risk concept is extremely important, so we wanted to see how companies in Romania define reputational risk. Thus, $71 \%$ of respondents define it as an independent risk and $29 \%$ consider it a consequence of another risk.

"Was reputational risk included in the company's risk inventory?" The results of the research showed that $64 \%$ of institutions include reputational risk in the company's risk inventory, $14 \%$ of institutions do not yet include reputational risk in the company's risk inventory but are considering including it, $22 \%$ of institutions do not include reputational risk in the inventory company risks.

When asked how did you integrate reputational risk into your institution's risk strategy, $46 \%$ of respondents said it was part of the organization's strategy, $25 \%$ of respondents said it was an independent strategy, and $29 \%$ had not yet included it explicitly in the strategy of the institution.

"How do you inform and train employees about the importance of reputational risk?" $43 \%$ of respondents declare through training programs, 32\% through e-mails, $25 \%$ do not notify them.

As we have found in the literature: reputational risks arise when the expectations of individual stakeholders are not met. That's why we asked: "who are the most important stakeholders for reputational risk?" $47 \%$ of respondents believe that the most important are customers, $21 \%$ of respondents say that the most important are shareholders, $14 \%$ said employees are the most important, $11 \%$ supervisory institutions, and $7 \%$ do not know.

Only $18 \%$ of the responding institutions claimed to have an independent reputational risk committee. $43 \%$ of respondents did not integrate reputational risk into other commissions and did not yet create a separate risk committee (Figure no. 3).

The results of the research show an awareness of the Romanian financial institutions in regard of reputational risk, but an early stage for managing this type of risk. Our recommendations are the inventory of the company's risks, the identification of the reputational risk, the creation of a special commission for this type of risk, the implementation of a reputational risk control process, its inclusion in the non-financial report. A risk culture should be promoted within the company and employees should adhere to a code of ethics regarding moral behavior and respect for the integrity of the workplace. Effective communication between the different hierarchical levels in the company can contribute to improving reputational risk management.

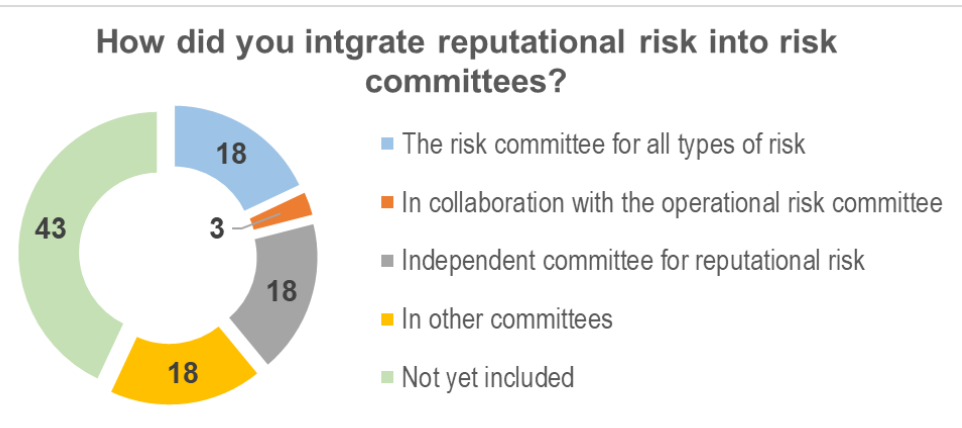

Figure no. 3. Integration of reputational risk in risk commissions 
Although most of the interviewed financial institutions are concerned with reputational risk, $43 \%$ of them have not implemented a separate committee responsible for reputational risks. Reputational risk control is in an early stage of development for Romania. There is an increased need for action to communicate transparently. The ultimate goal would be to raise awareness of the correct management of reputational risk. There is still no uniform procedure for risk managers.

\section{The analysis of the non-financial information published by the top banks in Romania}

The rationale behind the requirement to publish non-financial information is to make transparency a lever for the gradual transformation of systemic institutions - especially in the financial sector - into pillars to support sustainable economic and social development. Disclosure of non-financial information should lead institutions to more responsibly analyze the larger and longer-term impact of their activities. It is intended to generate competition between the institutions concerned to display superior performance, to gain trust, respect, admiration and support from society, in short for a better reputation. In order for the implementation of this obligation by large corporations in the financial system to have the expected result, it is necessary to go beyond the routine of publishing only that information that benefits the organization concerned. Point 5 of the explanatory memorandum to Directive 95/2014 states: Undertakings covered by this Directive should provide an overview, accurate and comprehensive of their policies, results and risks. It can even be said that non-financial reports are expected to highlight mainly the problematic aspects, commitments and progress of the organization in correcting processes with potential negative impact on the economy, the environment or people. This is exactly what we wanted to investigate by analyzing non-financial reports of 5 of the most influential banks in Romania.

A reference model is needed in the NFR research of the selected banks, as the requirements of the Directive, although clear, are formulated somewhat allusively, leaving quite a bit of freedom to the Member States and institutions concerned regarding the effective interpretation and application. In this regard, the model illustrated in Figure 4 was considered.

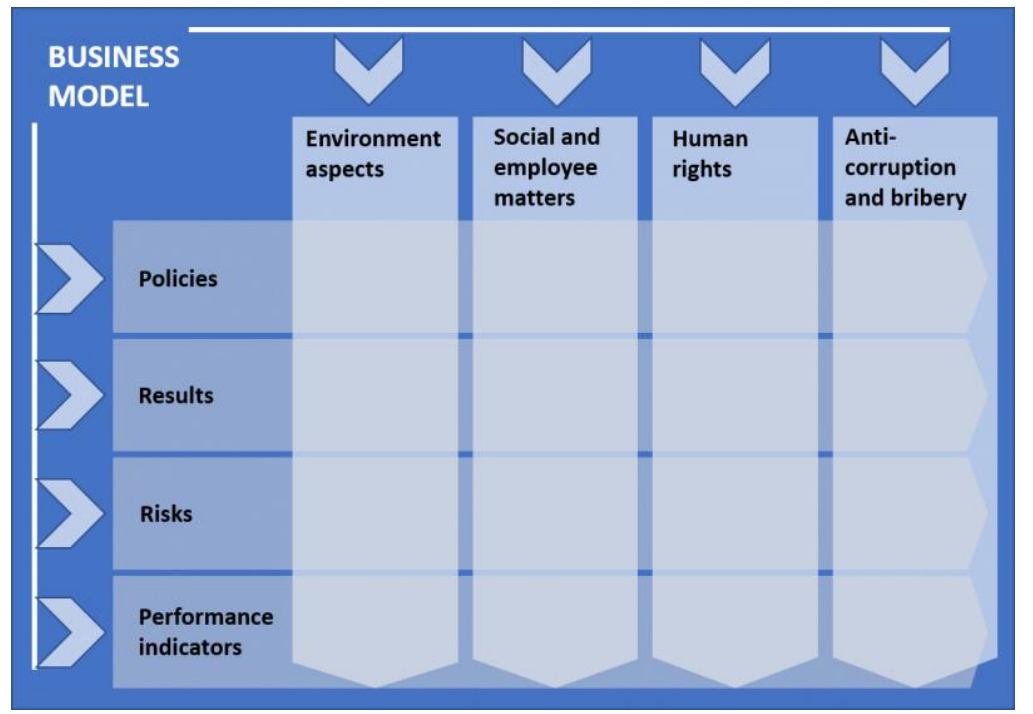

Figure no. 4. Non-financial reporting netting according to Directive 95/2014 
It must be said that a correct interpretation of the NFR requirements involves the interpenetration of several perspectives:

- firstly, there are three types of desideratum: (i) stability, (ii) resistance to shocks and crises and (iii) contribution to social and economic progress;

- secondly, the requirements of the NFR are intertwined with the rules of the Banking Supervisory Authority (BSA), the regulations of the Financial Services Authority (FSA), the rules applicable to the parent institution, requirements of international policies (UN Millennium Development Goals), the European Union (inclusion of ESG criteria for the bank supervision) or national criteria, social responsibility frameworks (like GRI), etc.; institutions must manage all these requirements in a unitary way, through an integrated system;

- thirdly, it should be emphasized that NFR requirements must be interpreted in the context of the business model and the actual operating conditions; for example, in the case of banks the risks of air or water pollution are probably less important than in the case of a chemical plant, but the problem of energy and material consumption can be significant;

- fourthly, the NFR must reflect the economic, social and environmental impact of its activity, both as a direct effect and as an effect propagated through other entities with which the institution concerned has links, including "where relevant and proportionally, its supply and subcontracting chains" (Directive 95/2014, paragraph 6 of the explanatory memorandum).

We included in the analysis the five most influential banks in Romania:

- Banca Transilvania - BT

- Banca Comercială Română - BCR, member of the Erste group;

- Banca Română de Dezvoltare - BRD, member of the Société Générale group;

- Raiffeisen Bank Romania - RB, member Raiffeisen Bank International - RBI group;

- ING Bank Romania - ING, member of the ING Bank group.

In 2018 , the five banks held together over $60 \%$ of the total assets of Romanian banks, being also in a position of role models in the bank industry.

For a start, it was necessary to identify the latest NFRs within the websites of the respective institutions. It should be noted that there is no single point where to find, or where to access all NFR of Romanian organizations that have the obligation to publish such a report. This situation contradicts the aim of making that information accessible to the general public and makes it difficult to make comparisons. In addition, non-financial information is sometimes placed on non-commercial sites or in certain investor sections, alongside documents with more technical content, as if the NFR were not of interest to regular customers or for the general public as well) under names or in groups whose names may differ. In short, the information is published, but you must know that it exists and you must look for it.

After having identified the documents, we analyzed their contents using the reference model described above as a guide. It should be noted that the analysis refers to the content of the document which, at least in principle, applies the provisions of Directive 95/2014. Some information not found in this document, although of interest, may be published elsewhere. We considered that it was not appropriate to extend the search to all the information published 
by banks, as the analysis strictly addresses the way in which the institutions concerned deal with non-financial reporting.

In the following, the main findings of the analysis are presented. The analyzed documents are indicated in the list of references, including the internet address (link) where they can be consulted. At the date of gathering information and conducting the analysis, the most recent NFR targeted 2018.

\section{General findings}

Only two of the five analyzed banks publish a document entitled Non-financial report, the first edition being the one referring to 2018. By this choice, the two institutions (BT and ING) show a certain receptivity to the requirements of NFR, a greater availability towards compliance and probably a better understanding of the usefulness of NFR. The other three banks publish annual reports that cover to a greater or lesser extent the obligation to make public the non-financial information. Raiffeisen's annual report is very comprehensive and detailed and largely covers NFR issues, albeit not in a compact and dedicated manner. BRD has chosen to publish elements of the NFR in the form of an annex to the annual report entitled Non-financial statement. Observing the different ways in which the analyzed banks chose to publish the non-financial information, the question that arises is which way would be more advisable? From the point of view of integrating all management policies and tools as well as in the perspective of including the ESG criteria in the field of banking supervision as part of a unitary annual report, it seems to be the better solution. On the other hand, the need for comparability in terms of non-financial reporting issues and the foreseeable evolution towards the adoption of a uniform system for NFRs including a single access point to them, would argue for the resolution of a separate report. In the same context, the relationship between NFR and CSR reports (and, in addition, ESG) should be clarified. Conceptually, there should be no difference. However, the need for clarification comes from the habit of exaggerating the association of CSR with charitable and patronage actions to the detriment of other issues such as organizational governance, loyal business practices, ethical behavior in labor relations, etc. We therefore believe that the institutions should review the way they understand and apply social responsibility policies. The recognition of the conceptual identity between NFR, CSR and ESG would represent a progress, in the sense of simplifying the taxonomy, on the one hand, and a rationalization of the management and reporting systems on the other hand.

In general, the analyzed reports cover the NFR themes: policies are declared and some concrete measures implemented are listed; some of these are presented together with their results; risk categories are listed rather than customized and assessed in temporal and spatial context, and performance indicators are only inserted from time to time. In terms of risks, all five banks mention the major threat posed by the introduction of an additional asset tax.

It is noted that a unitary and comprehensive methodological framework is not pursued especially a predetermined and made known one - but there are listed in particular those concerns and actions that put the organization in a favorable light, other aspects that would be of interest being simply ignored. It can be assumed that in the absence of a unitary methodological framework that could be given by the European Commission or the Romanian State, the structure of the report could be different from one year to another, 
without determining the commitment of medium and long term and without providing a solid benchmark for systematic improvement and progress monitoring.

All five analyzed banks understand their primary role and responsibility - by the nature of their business - to contribute to sustainable economic growth, especially by lending to the private sector, but also by supporting consumption. In this regard, banks report the results recorded and mention the initiatives to increase the favorable impact of their activity in the economy, as well as the innovations they have introduced or will introduce. They rarely present targets that they set for themselves in the future and nowhere have I found a report of the results to previously set targets.

With the exception of BCR, all the analyzed banks mention the concern for reputational risk. No information is provided on how the reputation and reputational risk issue is managed, nor are any threats analyzed. More openly, Raiffeisen devotes 4 fairly consistent paragraphs to reputational risk, mentioning the definition of a Reputational Risk Policy and providing a description of the instruments implemented by the bank to monitor this risk. BCR reports talk a lot about risks in general without naming certain categories of risks.

All five banks present in the NFR and/or CSR reports a multitude of initiatives and projects for society and the community (Annex 3 ). These cover areas such as the environment, culture, health, sports, etc. and takes place in partnership with civil society and/or public institutions. Budgets, amounts and/or project results are mentioned in a non-systematic way. For larger projects, it would have been interesting to have further impact assessments, as such projects would be better to target larger-scale effects, beyond the immediate results.

\section{Notable aspects - good practices ... or not}

The promotion of financial education among the population and entrepreneurship occupies an important place in the portfolios of actions in favor of the society/community of the analyzed banks.

Financial education programs (where BCR is most strongly involved) are an example of good practice, while the involvement of banks in entrepreneurship education involves at least one discussion. Financial education is a major social need in Romania, a country that ranks last in Central and Eastern Europe and 124th out of 141 worldwide in terms of financial education of the population. A population with a good financial education creates a more stable and predictable economic environment, ensures greater economic and financial security for households, induces a more demanding and responsible consumption behavior. At the same time, a good financial education will contribute to the extension of financial intermediation, with a favorable effect on the financial-banking sector. In addition, the financial services market will become better informed and more demanding by allowing the deployment of truly good financial institutions. Banks, along with other financial sector institutions, are the most important repository of financial knowledge and skills, with a moral responsibility to contribute to improving the financial education of the population. It is difficult to imagine a more appropriate area for banks to intervene in favor of society. If we discuss these initiatives not only in terms of short-term results, but in terms of impact, we need to refer to the concept of critical mass of intervention and time horizon to make a significant change. The individual initiatives of the different banks will help to increase the reputation of those banks, but not much. Given the interference between the reputation of any bank and the reputation of the 
banking industry, the reputation of banks could gain more if such a project were carried out jointly, possibly under the patronage of the Romanian Association of Banks. In this way, the critical mass could be reached and a significant impact could be registered in a reasonable period of time.

As far as the entrepreneurship education is concerned, things are different. Entrepreneurial education and the development of entrepreneurship are different concepts as compared to financing small and medium enterprises. The culture of banks contradicts the entrepreneurial spirit. So, banks intervention in this area, even if it could bring a short-term image benefit, is very likely to translate into a medium - and long-term reputational loss. In addition, some involvement in this area may raise concerns about conflicts of interest. If we want to support new innovative enterprises - considering the vocation of universal bank of Romanian banks - we can imagine that it is more appropriate to set up venture capital subsidiaries, with the bank's own money.

In relation to the impact on the environment, banks reputations can be much more severely affected by involvement in financing controversial projects than by direct effects of their own activity. BRD and ING are distinguished by the fact that they have adopted and implemented the application of the Equator principles, an advanced initiative of credit institutions for the assessment and prevention of environmental and social risks. Through this, the two institutions promote a much more demanding verification of the projects for which financing is requested, compared to the verification of the legal compliance practiced by the other analyzed banks. Specifically, BRD adopted a set of sectoral policies including bans on the financing of certain types of projects with a high risk for the environment and stopped the financing of projects for coal-fired power plants.

Regarding the personnel policies, despite formal statements on the recognition of the benefits that greater diversity would bring, the non-financial reports show a rather cautious attitude towards promoting more equitable balances. One reason could be that Romanian banks do not perceive significant risks in this direction. The BT report shows quite directly that it does not understand to discriminate on the basis of gender, age, etc. not even to ensure a more balanced representation of the different categories. Precisely because of this reluctance, when publishing certain indicators, banks provide irrelevant information instead of more in-depth analysis. For example, it would be interesting to see what is the ratio between the average net income of women and that of men or the ratio between the sexes on different hierarchical levels, etc.

As employers, banks enjoy a good reputation. In the Catalyst Solutions survey of the most desired employers, the five banks included in our analysis are perfectly grouped occupying positions 11-15 in the ranking (Catalyst, 2019). This could be more than just a coincidence, i.e. it could indicate a uniformity of personnel policies, a non-combative attitude in attracting staff. Care for staff is manifested by investing in training programs and providing benefits in the form of health services (Annex 2). A notable example is the life-saving screening program for early detection of cancer for the BT employees. Beyond these specific projects, however, the image of banks would gain and their reputation would be better protected if they undertook a more careful assessment of occupational diseases and took certain measures to reduce exposure to physical and mental stressors of staff.

Banks state that they comply with the requirements of the rules and standards on appointment to decision-making and that they apply remuneration (compensation) policies that avoid 
stimulating excessive risk-taking. However, they do not publish data - even aggregated or in relative figures - that would allow an assessment of the facts or comparisons. This reluctance to go one step further in terms of transparency exposes them to increased reputational risks in the event of disclosures.

With regard to human rights, reports show that the bank respects human rights and that no incidents have been reported. Also, in this field it can be appreciated that the reputational risk is still low in Romania. However, banks do not indicate the existence of a mechanism for identifying the risks of human rights violations in the process of evaluating projects submitted for financing, nor the concern to include human rights clauses in financing contracts. Adopting such work routines and publishing them in the NFR could mitigate the reputational risk in the event of incidents.

It is plausible that the banks included in our analysis have robust systems to combat any form of internal corruption. The risk to their reputation comes mainly from external partners and the projects they finance. This risk is considerable, as has been repeatedly shown. ING, BRD and BCR describe certain concrete measures, consisting of the adoption of codes of conduct and the training of staff to identify and prevent the risks associated with some forms of corruption.

\section{Overall assessments resulting from NFR analysis}

Although responding to the obligation to make public non-financial information established by Directive 95/2014 transposed by OMPF 1938/2016, the NFRs of the banks included in the analysis are relatively difficult to access to the public and differ greatly in terms of information content, level of detail and level of concreteness, the degree of processing and the significance of the performance indicators, etc. Therefore, any attempt to compare or classify the published information can only be risky at this stage. Despite all these difficulties, we believe that a number of overall assessments can be made:

- the analyzed NFRs show that the respective banks are increasingly aware of the reputational risk, on the one hand, and understand the need to respond by disclosing nonfinancial information to the legitimate concerns of the stakeholders, on the other hand; given that the selected banks are the most advanced institutions of the financial sector in Romania, their practices regarding reputational risk management and non-financial reporting can be considered role models for other financial institutions as well;

- there is a positive correlation between the pride of having a good reputation and the willingness to communicate more non-financial information in a more accessible form to the public; this is easy to notice in the case of RB (which lists the distinctions received at the beginning of the annual report) and in the case of BT (also awarded by the Bucharest Stock Exchange for the non-financial report they presented);

- it is quite obvious the reluctance to make known to interested parties' things that are known not to work as desired, the concern and commitment to correct them;

- in many situations the information is provided as such, without being able to understand the position of the respective institution towards the respective factual situation; for example, the RB report presents the structure of the bank's partners in community projects, which shows an increase in the share of public institutions, to the detriment of non-profit 
institutions, but it cannot be deduced whether this is a coincidence or the result of a deliberate policy (Raiffeisen, 2019, p. 28).

\section{Conclusions}

Reputation is an important factor in competitiveness. This is true for all contemporary organizations, but it is even more important for the financial sector institutions, due to their systemic role in the economy. The company expects banks and other financial system institutions to genuinely commit to higher goals, beyond the traditional concern for short-term financial results. Reputational risk management, without losing sight of operational aspects, must encompass these two dimensions: high(er) goals and authenticity. This is only possible with the help of top management of the respective institutions and through a process of transformation of the whole organizations.

NFR can be seen as another administrative obligation or burden imposed on financial sector institutions. It would be better, however, for the institutions concerned to adopt it as an opportunity, a tool for nurturing a good reputation and a shield against unfair attacks.

In the Romanian financial sector, reputational risk management and control are at an early stage of development, with inconsistent views on governance issues, methods and processes. Our study shows that, although an increasing number of institutions incorporates a concern about reputational risk, it is generally considered a vague concept and treated largely as a marginal issue.

Through NFR, banks must convince customers that they are pursuing purposes other than commercial. Banks publish non-financial results on their official websites, in the annual consolidated report or in a separate CSR report. It should be noted that all banks have previously reported that the measure of Directive 2014/95 / EU will become mandatory for Romania. The first CSR reports available online have been since 2009.

A standard model for reporting non-financial results is not yet available in Romania. It allows each institution to provide the information that puts it in a more favorable light, in particular community-based philanthropic and charitable projects, to the detriment of investigating the economic and social impact of their business. Institutions are not yet fully aware that by doing so, they are becoming more vulnerable in terms of reputational risk. Unconfessed (and uncorrected) weaknesses can be revealed, with serious damage, difficult to repair. A standardized NFR model would be welcomed. Such a model could be promoted by the European Commission. For banks, however, the next stage is more likely to be the incorporation of ESG among the banking supervision criteria, a project for which the EBA has already received a mandate.

It is advisable that banks and other financial institutions prepare in advance, in a proactive manner, for future implementation needs. It can be anticipated that profound changes in organizational culture will be needed, that reputational risk will play a central role among the concerns of top management of financial sector institutions and that full transparency will become the main tool for strengthening and protecting reputation.

The authors of this paper are aware of the limitations of the research and recommend readers to avoid any generalizations or exaggerated interpretations. The main limitation of the study is the absence of a point of view of the research institutions. In this regard, further research 
with a series of in-depth interviews would be welcome. At the same time, the situation presented is the photograph of a state of affairs, captured at a certain moment; further investigations are needed to describe the dynamics, especially with regard to NFR.

List of abbreviations

\begin{tabular}{|l|l|l|l|}
\hline ASF & $\begin{array}{l}\text { Autoritatea de Supraveghere } \\
\text { Financiară } \\
\text { (The Financial Supervisory Authority) }\end{array}$ & EY & Ernst \& Young \\
\hline BCBS & $\begin{array}{l}\text { Basel Committee on Banking } \\
\text { Supervision }\end{array}$ & GRI & Global Reporting Initiative \\
\hline BCR & $\begin{array}{l}\text { Banca Comercială Română } \\
\text { (Romanian Commercial Bank) }\end{array}$ & ING & Internationale Nederlanden Groep \\
\hline BNR & $\begin{array}{l}\text { Banca Națională a României } \\
\text { (The National Bank of Romania) }\end{array}$ & RB & Raiffeisen România \\
\hline BRD & $\begin{array}{l}\text { Banca Română de Dezvoltare } \\
\text { (Romanian Bank for Development) }\end{array}$ & RBI & Raiffeisen Bank International \\
\hline BT & $\begin{array}{l}\text { Banca Transilvania } \\
\text { (Transilvania Bank) }\end{array}$ & RepTrak & $\begin{array}{l}\text { Rep Trak Organization (before: } \\
\text { Reputation Institute) }\end{array}$ \\
\hline CHF & Swiss franc & NFR & Non-financial reporting \\
\hline EBA & European Banking Authority & CSR & Corporate Social Responsibility \\
\hline ESG & $\begin{array}{l}\text { Environmental, social and governance } \\
\text { (criteria) }\end{array}$ & UN & United Nations \\
\hline
\end{tabular}

\section{References}

Adamoae, A.M., 2012. Fraudă bancară de 22 de milioane de euro. Președintele BRD: „Documentele trec prin 10-12 mâini. E greu de crezut că sunt toți corupți”. EVZ.RO [online] (Last updated 1 November 2012). Available at: <https://evz.ro/cea-mai-marefrauda-din-sistemul-bancar-romanesc-1008743.html > [Accessed on 10 January 2020].

Arvinte A., 2018. Alertă bancară în România. Cum a fost devalizată BRD de zeci de milioane de euro. [press release] 12 September 2018. Available at: <https://evz.ro/brd-devalizatamilioane-euro.html> [Accessed 5 January 2020].

Auge-Dickhut, S., Egloff, P., Haasner, W. and Koye, B., 2015. Zukunftsfähigkeit von Schweizer Banken. [pdf] Kalaidos Fachhochschule Schweiz. Available at: <http://www.koyepartner.ch/de/medien/01-Buecher-und-Beitraege/2015.01_augekoye_Zukunftsfaehigkeit-von-Schweizer-Banken_Compendio.pdf $>$ [Accessed 5 January 2020].

Barnett, M.L. and Pollock, T.G., 2012. Charting the Landscape of Corporate Reputation Research. [online] Oxford University Press. Available at: <http://oxfordhandbooks.com/ view/10.1093/oxfordhb/9780199596706.001.0001/oxfordhb-9780199596706-e-1> [Accessed 6 January 2020].

Barnett, M.L., Jermier, J.M. and Lafferty, B.A., 2006. Corporate Reputation: The Definitional Landscape. Corporate Reputation Review, 9(1), pp.26-38.

BCBS, 2009. Enhancements to the Basel II Framework. [pdf] Basel Committee on Banking Supervision. Available at: <http://www.bis.org/publ/bcbs157.pdf> [Accessed 10 January 2020]. 
BCBS, 2010. Principles for enhancing corporate governance. [pdf] Basel Committee on Banking Supervision. Available at: <http://www.bis.org/publ/bcbs176.pdf > [Accessed 10 January 2020].

BCBS, 2015. Guidelines. Corporate governance principles for banks. [online] Bank for International Settlements. Available at: <https://www.bis.org/bcbs/publ/d328.htm> [Accessed 10 January 2020].

BCR, 2010. Raport de responsabilitate socială 2009-2010. [pdf] Banca Comercială Română Available at: <https://www.bcr.ro/ /CSR/Rapoarte/Raport_BCR_CSR_RO_2009_ 2010.pdf $>$ [Accessed 5 January 2020].

BCR, 2018. Raport de transparență 2017. [pdf] Banca Comercială Română. Available at: $<$ https://www.bcr.ro/content/dam/ro/bcr/Investitori/Raport_de_transparenta_interimarH1_2017.pdf > [Accessed 5 January 2020].

Bennett, R. and Kottasz, R., 2000. Practitioner perceptions of corporate reputation: an empirical investigation. Corporate Communications: An International Journal, 5(4), pp.224-235.

BNR, 2020. Registrul instituțiilor de credit. [online] Available at: <https://www.bnr.ro/files/d/RegistreBNR/InstitCredit/ban1_raport.html> [Accessed 5 January 2020].

Booth, S.A., 2000. How Can Organizations Prepare for Reputational Crises? Journal of Contingencies and Crisis Management, 8(4), pp.197-207.

BRD, 2019. Raport anual 2018. [pdf] Available at: <https://www.brd.ro/_files/ pdf/2.2\%20BoD\%20report\%202018\%20RO.pdf> [Accessed 5 January 2020].

BT (Banca Transilvania), 2019. Raport non-financiar de mediu, social și de guvernanță 2018. [pdf] Available at: <https://www.bancatransilvania.ro/files/carte-de-vizita/ raportnonfinanciardemediusocialsideguvernanta2018.pdf > [Accessed 5 January 2020].

Burkhardt, R., 2008. Reputation Management in Small and Medium-Sized Enterprises: Analysis and Evaluation of the Use of Reputation Management; A Survey of Small and Medium-Sized Enterprises in Germany. Hamburg: Diplomica Verl.

Carreras, E., Alloza, A. and Carreras, A., 2013. Corporate reputation. London: LID Publishing.

Catalyst, 2019. Cei Mai Doriți Angajatori 2019 - Romania [online] Available at: <https://www.catalyst.ro/top-cei-mai-doriti-angajatori-2019-2/> [Accessed 7 January 2020].

Comité Européen des Assurances (CEA), Groupe Consultatif Actuariel Européen, 2007. Solvency II Glossary. [pdf] Available at: <http://ec.europa.eu/internal_market/insurance/docs/ solvency/impactassess/annex-c08d_en.pdf> [Accessed 10 January 2020].

Corporate Citizenship, 2020. Corporate Citizenship [online] Available at: <https://corporatecitizenship.com/service/lbg/> [Accessed 7 January 2020].

Deloitte, 2020. 2020 banking and capital markets outlook. [online] Deloitte Belgium. Available at: <https://www2.deloitte.com/be/en/pages/financial-services/articles/2020banking-and-capital-markets-outlook.html> [Accessed 20 March 2020].

Dowling, G., 2006. Reputation risk: it is the board's ultimate responsibility. Journal of Business Strategy, 27(2), pp.59-68.

EBA, 2019. EBA Action Plan on Sustainable Finance. [online] Available at: $<$ https://eba.europa.eu/sites/default/documents/files/document_library//EBA\%20Action\%20 plan\%20on\%20sustainable\%20finance.pdf > [Accessed 7 January 2020]. 
Eccles, R.G., Newquist, S.C. and Schatz, R., 2007. Reputation and its risks. Harvard Business Review, 85(2), pp.104.

Eckert, C., 2017. Corporate Reputation and Reputation Risk: Definition and Measurement From a (Risk) Management Perspective. The Journal of Risk Finance, 18(2), pp.145-158. doi:10.1108/JRF-06-2016-0075.

EY, 2017. Global Banking Outlook 2017. Uncertainty is no excuse for inaction. [pdf] Available at: <https://www.ey.com/Publication/vwLUAssets/EY-global-banking-outlook-2017/\$ FILE/EY-global-banking-outlook-2017.pdf> [Accessed 10 January 2020].

EY, 2020. Banking in the new decade. Three big bets to boost profitability and free up capital to invest in transformation. [pdf] Available at: <https://assets.ey.com/content/dam/eysites/ey-com/en_gl/topics/banking-and-capital-markets/ey-banking-in-the-new-decadethree-big-bets-to-boost-profitability-and-free-up-capital-to-invest-intransformation.pdf> [Accessed 20 March 2020].

FED - Board of Governor of Federal Reserve System. 1995. Rating the adequacy of risk management processes and internal controls at state member banks and bank holding companies. Supervisory Letter, SR Letter 95-51, 14 November. [online] Available at: <http://www.federalreserve.gov/boarddocs/srletters/1995/sr9551.htm> [Accessed 7 January 2020].

Federal Financial Institutions Examination Council (FFIEC). 2010. Retail Payment Systems. [online] Available at: 〈http://ithandbook.ffiec.gov/it-booklets/retail-payment-systems.aspx> [Accessed 7 January 2020].

Fiordelisi, F., Soana, M.-G. and Schwizer, P., 2014. Reputational Losses and Operational Risk in Banking. The European Journal of Finance, 20(2), pp.105-124.

Fombrun, C. and Shanley, M., 1990. What's in a Name? Reputation Building and Corporate Strategy. Academy of Management Journal, 33(2), pp.233-258.

Fombrun, C.J. and van Riel, C.B.M., 1997. The Reputational Landscape. Corporate Reputation Review, 1(1), pp.5-13.

Fombrun, C.J., 1996. Reputation: Realizing Value From the Corporate Image. Boston, Mass: Harvard Business School Press.

Fombrun, C.J., 2012. The Building Blocks of Corporate Reputation: Definitions, Antecedents, Consequences. [online] Oxford University Press. Available at: <http://oxfordhandbooks.com/view/10.1093/oxfordhb/9780199596706.001.0001/oxfordhb9780199596706-e-5> [Accessed 7 January 2020].

Fombrun, C.J., Gardberg, N.A. and Barnett, M.L., 2000. Opportunity Platforms and Safety Nets: Corporate Citizenship and Reputational Risk. Business and Society Review, 105(1), pp.85-106.

Forcadell, F.J. and Aracil, E., 2017. European Banks' Reputation for Corporate Social Responsibility. Corporate Social Responsibility and Environmental Management, 24(1), pp.1-14.

Gatzert, N., 2015. The Impact of Corporate Reputation and Reputation Damaging Events on Financial Performance: Empirical Evidence from the Literature. European Management Journal, 33(6), pp.485-499.

Gatzert, N., Schmit, J.T. and Kolb, A., 2016. Assessing the Risks of Insuring Reputation Risk. Journal of Risk and Insurance, 83(3), pp.641-679. doi:10.1111/jori.1206. 
Ghiţă, S.I., Gogonea, R.M. and Săseanu, S.A., 2019. Manifestations of the European Ecological Footprint from the Perspective of Social Responsibility Codes. Amfiteatru Economic, 21(52), pp. 554-571.

Global Reporting (GRI). 2020. Global Reporting [online] Available at: <https://www.globalreporting.org/standards> [Accessed 5 January 2020].

Gotsi, M. and Wilson, A.M., 2001. Corporate reputation: seeking a definition. Corporate Communications: An International Journal, 6(1), pp.24-30.

Helm, S., 2011. Corporate Reputation: An Introduction to a Complex Construct. In: Helm S., Liehr-Gobbers K., Storck C. (eds) Reputation Management. Management for Professionals. Springer, Berlin, Heidelberg, pp 3-16. https://doi.org/10.1007/978-3-642-19266-1_1.

ING, 2019. 2018 Annual Report ING Bank N.V. [pdf] Available at: <https://www.ing.com/ Investor-relations/Financial-performance/Annual-reports/2018.htm> [Accessed 5 January 2020].

Investorpedia - Reputational Risk. 2019. Reputational Risk. [online] Available at: <https://www.investopedia.com/terms/r/reputational-risk.asp> [Accessed 5 January 2020].

Jo, H., Kim, H. and Park, K., 2015. Corporate environmental responsibility and firm performance in the financial services sector. Journal of Business Ethics, 131(2), pp.257-284.

Kaiser, T., 2010. Reputationsmanagement in Banken. Zeitschrift für das gesamte Kreditwesen, 3(2010), pp.17-20.

KPMG, 2012. Reputationsrisiko: Management und Controlling: Status quo und Perspektiven der Weiterentwicklung im Finanzsektor. [pdf] Available at: <https://assets.kpmg/ content/dam/kpmg/pdf/2013/02/reputationsrisiko-management-controlling-2012KPMG.pdf> [Accessed 5 January 2020].

Larkin, J., 2003. Strategic Reputation Risk Management. London: Palgrave Macmillan.

MFP, 2016. Ordinul Nr. 1938/2016 din 17 august 2016 privind modificarea şi completarea unor reglementări contabile. [pdf] Available at: <https://static.anaf.ro/static/10/ Anaf/legislatie/ OMFP_1938_2016.pdf> [Accessed on 05 January 2020].

Obama, B.H., 2009. Inaugural Address. [online] Available at: <https://obamawhitehouse. archives.gov/blog/2009/01/21/president-barack-obamas-inaugural-address> [Accessed 17 March 2020].

Pérez, A. and Rodríguez del Bosque, I., 2015. How customer support for corporate social responsibility influences the image of companies: Evidence from the banking industry. Corporate Social Responsibility and Environmental Management, 22(3), pp.155-168.

Plunus, S., Gillet, R. and Hübner, G., 2012. Reputational Damage of Operational Loss on the Bond Market: Evidence From the Financial Industry. International Review of Financial Analysis, 24(4), pp.66-73.

Principles for Responsible Banking, 2020. Principles for Responsible Banking [online] Available at: <https://www.unepfi.org/> [Accessed 5 January 2020].

Radomir, L., Wilson, A. and Scridon, M.A., 2011. Improving Bank Quality Dimensions to Increase Customer Satisfaction, Journal of Management and Marketing, 9(1), pp.126-148.

Raiffeisen Bank, 2018. Raport de sustenabilitate 2017. [pdf] Available at: <https://www.raiffeisen.ro/despre-noi/media/comunicate-de-presa/2018/raportul-desustenabilitate-pentru-2017.pdf> [Accessed 5 January 2020]. 
Raiffeisen Bank, 2019. Raport anual 2018. [pdf] Available at: <https://www.raiffeisen.ro/ despre-noi/guvernanta-corporativa/rapoarte-anuale/> [Accessed 5 January 2020].

Rasheed, S., 2014. Reputation Risk Management in Financial Firms: Protecting (Some) Small Investors. Journal of Financial Regulation and Compliance, 22(4), pp.286-299. doi:10.1108/JFRC-11-2013-0040.

Reuters, 2018. Dutch bank ING fined $\$ 900$ million for failing to spot money laundering. [online] Available at: <https://www.reuters.com/article/us-ing-groep-settlement-moneylaundering/dutch-bank-ing-fined-900-million-for-failing-to-spot-money-launderingidUSKCN1LK0PE> [Accessed 7 January 2020].

Sabater, J. and Sierra, C., 2002. Reputation and Social Network Analysis in Multi-Agent Systems. In: Proceedings of the first International Joint Conference on Autonomous Agents and Multiagent Systems (AAMAS-02). Bologna, Italy, pp.475-482.

Sarstedt, M., Wilczynski, P. and Melewar, T.C., 2013. Measuring Reputation in Global Markets - A Comparison of Reputation Measures' Convergent and Criterion Validities. Journal of World Business, 48(3), pp.329-339.

Startarium.ro, 2020. Te afli în orașul antreprenorilor. [online] Available at: <https://www.startarium.ro/> [Accessed 7 January 2020].

Suryanto, T., 2016. Dividend policy, information technology, accounting reporting to investor reaction and fraud prevention. International Journal of Economic Perspectives, 10(1), pp.138-150.

Sustainability disclosure database, 2020. Sustainability disclosure database. [online] Available at: <https://database.globalreporting.org/search/> [Accessed 5 January 2020].

Thalassinos, I.E. and Liapis, K., 2014. Segmental financial reporting and the internationalization of the banking sector. In: D. Milos Sprcic, ed. 2014. Risk Management: Strategies for Economic Development and Challenges in the Financial System. Hauppauge, New York: Nova Science Publishers, Inc. pp.221-255.

Tonello, M., 2007. Reputation Risk: A Corporate Governance Perspective. SSRN Electronic Journal. [online] Available at: <http://www.ssrn.com/abstract=1077894> [Accessed 5 January 2020].

United Nations Global Compact, 2020. Uniting business for a better world. [online] Available at: <https://www.unglobalcompact.org/what-is-gc/mission/principles> [Accessed 5 January 2020].

Walker, K., 2010. A Systematic Review of the Corporate Reputation Literature: Definition, Measurement, and Theory. Corporate Reputation Review, 12(4), pp.357-387.

Walter, I., 2014. Reputational risk in banking and finance: an issue of individual responsibility? J Risk Manag Finan Ins, 7(3), pp.299-305.

Weber, O., 2012. Environmental Credit Risk Management in Banks and Financial Service Institutions. Business Strategy and the Environment, 21(4), pp.248-263.

Weber, O., Hoque, A. and Ayub Islam, M., 2015. Incorporating Environmental Criteria Into Credit Risk Management in Bangladeshi Banks. Journal of Sustainable Finance \& Investment, 5(1-2), pp.1-15.

Wu, M.W. and Shen, C.H., 2013. Corporate social responsibility in the banking industry: Motives and financial performance. Journal of Banking \& Finance, 37(9), pp.3529-3547. 
Annex no. 1: List of financial institutions to which the reputational risk management questionnaire was sent

\begin{tabular}{|c|c|c|}
\hline Alpha Bank România & BRD - Groupe Société Générale & Raiffeisen Banca pentru Locuințe \\
\hline Banca Română de Credite și & CEC Bank & UniCredit Bank \\
\hline Investiții & Crédit Agricole Bank România & BCR Leasing IFN \\
\hline Banca Comercială Feroviara & Credit Europe Bank (România) & BRD Finance IFN \\
\hline Banca Comercială Intesa Sanpaolo & Garanti Bank & ING Commercial Finance IFN \\
\hline România & Idea Bank & ING credit IFN, ING lease Romania IFN \\
\hline Banca Transilvania S.A. & Libra Internet Bank & Patria credit IFN \\
\hline Banca Comercială Română (BCR) & Vista Bank & Profi credit Romania IFN \\
\hline BCR Banca pentru Locuințe & OTP Bank România & Provident financial Romania IFN \\
\hline Banca de Export-Import a României & Patria Bank & Quick leasing IFN \\
\hline Eximbank & First Bank & Raiffeisen leasing IFN \\
\hline Banca Românească - Membra a & Porsche Bank România & Ralfi IFN \\
\hline Grupului National Bank of Greece & ProCredit Bank & RCI Leasing Romania IFN \\
\hline Bank Leumi România & Raiffeisen Bank & Regio Leasing IFN \\
\hline
\end{tabular}

Annex no. 2: Projects for own staff (selection)

\begin{tabular}{|c|c|c|c|c|}
\hline Banca Transilvania BT & $\begin{array}{l}\text { Banca Comercială } \\
\text { Română BCR }\end{array}$ & $\begin{array}{l}\text { Banca Română de } \\
\text { Dezvoltare BRD }\end{array}$ & Raiffeisen Romania & ING Bank Romania \\
\hline $\begin{array}{l}\text { Recruitment through } \\
\text { LinkedIn } \\
\text { LinkedIn and BT project } \\
\text { to increase the visibility } \\
\text { of BT vacancies and head- } \\
\text { hunting approach of } \\
\text { experienced candidates }\end{array}$ & $\begin{array}{l}\text { Training programs for } \\
\text { managerial functions } \\
\text { *management of change; } \\
\text { * time management \& } \\
\text { feedback as a tool for } \\
\text { personal development }\end{array}$ & $\begin{array}{l}\text { "BRD ID matters!" } \\
\text { discounts that BRD } \\
\text { employees can benefit } \\
\text { from }\end{array}$ & $\begin{array}{l}\text { RStyle } \\
\text { "RStyle" means improving } \\
\text { health, self-knowledge } \\
\text { and personal } \\
\text { development programs, } \\
\text { improving professional } \\
\text { relationships }\end{array}$ & $\begin{array}{l}\text { Managerial and } \\
\text { Leadership Skills Training } \\
\text { Top management training } \\
\text { programs }\end{array}$ \\
\hline $\begin{array}{l}\text { BT Journey: "Take the } \\
\text { first step towards a } \\
\text { successful career" } \\
\text { Internship program }\end{array}$ & $\begin{array}{l}\text { Retail network training } \\
\text { programs } \\
\text { improving sales skills and } \\
\text { informing employees } \\
\text { about new products and } \\
\text { services }\end{array}$ & $\begin{array}{l}\text { Training and risk } \\
\text { awareness } \\
\text { Development of risk } \\
\text { culture within BRD } \\
\text { through e-learning } \\
\text { courses }\end{array}$ & $\begin{array}{l}\text { LEAD } 2 \text { Leadership } \\
\text { training program for top } \\
\text { management }\end{array}$ & $\begin{array}{l}\text { Banking Skills Training } \\
\text { The right person in the } \\
\text { right place, hiring } \\
\text { according to skills and } \\
\text { competencies }\end{array}$ \\
\hline $\begin{array}{l}\text { First Time Manager } \\
\text { Training program for BT } \\
\text { managers }\end{array}$ & $\begin{array}{l}\text { BCR and the union have } \\
\text { created a partnership on } \\
\text { pregnant employees } \\
\text { Monitoring the working } \\
\text { conditions of pregnant } \\
\text { employees }\end{array}$ & $\begin{array}{l}\text { Behavioral training } \\
\text { programs } \\
\text { In relationship with } \\
\text { clients, stress } \\
\text { management, conflict } \\
\text { management, teamwork }\end{array}$ & $\begin{array}{l}\text { Raiffeisen Banker } 2 \text { Be } \\
\text { recruitment for front } \\
\text { office positions, but also a } \\
\text { way to facilitate the } \\
\text { employment of new } \\
\text { graduates }\end{array}$ & $\begin{array}{l}\text { Mandatory Awareness } \\
\text { Training } \\
\text { Awareness training } \\
\text { programme }\end{array}$ \\
\hline $\begin{array}{l}\text { BT Con } \\
\text { training program: team } \\
\text { cohesion, learning and } \\
\text { social responsibility for } \\
\text { BT employees }\end{array}$ & $\begin{array}{l}\text { Star } \\
\text { offers official recognition } \\
\text { to BCR employees with } \\
\text { more than } 6 \text { months of } \\
\text { experience in the } \\
\text { organization }\end{array}$ & $\begin{array}{l}\text { Bookster } \\
\text { a modern library that } \\
\text { offers books directly at } \\
\text { the office, but also an } \\
\text { online platform where } \\
\text { employees can borrow } \\
\text { books }\end{array}$ & $\begin{array}{l}\text { Raiffeisen IT Trainee \& } \\
\text { Raiffeisen Management } \\
\text { Trainee } \\
\text { Training programme }\end{array}$ & $\begin{array}{l}\text { Orange Code "I for } \\
\text { integrity" } \\
\text { The integrity program for } \\
\text { ING employees in which } \\
\text { they assume to be } \\
\text { honest, responsible and } \\
\text { prudent }\end{array}$ \\
\hline $\begin{array}{l}\text { Screening saves lives } \\
\text { program for the } \\
\text { prevention of the most } \\
\text { common types of cancer. } \\
\text { Program for BT } \\
\text { employees. }\end{array}$ & $\begin{array}{l}\text { Summer job in BCR } \\
\text { Paid internship }\end{array}$ & $\begin{array}{l}\text { Parenting seminars } \\
\text { My child's needs }\end{array}$ & $\begin{array}{l}\text { Employee opinion survey } \\
\text { for the level of } \\
\text { commitment and } \\
\text { efficiency among } \\
\text { employees }\end{array}$ & $\begin{array}{l}\text { Think Forward } \\
\text { Leadership Programme } \\
\text { (TFLP) } \\
\text { Training programme for } \\
\text { top management }\end{array}$ \\
\hline $\begin{array}{l}\text { BT Director's Exchange } \\
\text { Programme } \\
\text { Strategic leadership } \\
\text { programme }\end{array}$ & $\begin{array}{l}\text { The career laboratory } \\
\text { Analysis of career } \\
\text { development } \\
\text { perspectives in BCR }\end{array}$ & $\begin{array}{l}\text { Organizing seminars on } \\
\text { health } \\
\text { eye consultation, dental } \\
\text { assessments for } \\
\text { employees and } \\
\text { Mindfulness Based Stress } \\
\text { Reduction }\end{array}$ & $\begin{array}{l}\text { Diversity Charter } \\
\text { commitment to promote } \\
\text { diversity, non- } \\
\text { discrimination, inclusion } \\
\text { and equal opportunities } \\
\text { in the workplace }\end{array}$ & $\begin{array}{l}\text { International Talent } \\
\text { Program } \\
\text { Maintaining staff within } \\
\text { ING Bank and personal } \\
\text { development }\end{array}$ \\
\hline
\end{tabular}


Annex no. 3: Banks projects for the society and local community (selection)

\begin{tabular}{|c|c|c|c|c|}
\hline Banca Transilvania BT & $\begin{array}{l}\text { Banca Comercială } \\
\text { Română BCR }\end{array}$ & $\begin{array}{l}\text { Banca Română de } \\
\text { Dezvoltare BRD }\end{array}$ & Raiffeisen Romania & ING Bank Romania \\
\hline $\begin{array}{l}\text { Cluj has soul } \\
\text { supports young people } \\
\text { without opportunities to } \\
\text { continue their schooling, } \\
\text { to qualify and to find a job }\end{array}$ & $\begin{array}{l}\text { My finances } \\
\text { financial educationfor } \\
\text { high school students, in } \\
\text { partnership with Junior } \\
\text { Achievement Romania }\end{array}$ & $\begin{array}{l}\text { Scena9 } \\
\text { supports cultural activity } \\
\text { (film, theater, museums, } \\
\text { art, concerts, books) }\end{array}$ & $\begin{array}{l}\text { Via TRANSILVANICA } \\
\text { Arranging a } 1000 \mathrm{~km} \text { route } \\
\text { for pilgrims }\end{array}$ & $\begin{array}{l}\text { Tandem Navigator } \\
\text { urban mobility project for } \\
\text { the visually impaired }\end{array}$ \\
\hline $\begin{array}{l}\text { MagicPayfor MagiCamp } \\
\text { helpingchildren with } \\
\text { cancer }\end{array}$ & $\begin{array}{l}\text { Bank of the responsible } \\
\text { children } \\
\text { pilot project of financial } \\
\text { education for children }\end{array}$ & $\begin{array}{l}\text { White night of the } \\
\text { galleries } \\
\text { promoting contemporary } \\
\text { art }\end{array}$ & $\begin{array}{l}\text { Elevator Lab Bootcamp } \\
\text { Romania } \\
\text { entrepreneurial education } \\
\text { for fintech entrepreneurs }\end{array}$ & $\begin{array}{l}\text { Urbaniada } \\
\text { Sustains solutions for } \\
\text { improving life inurban } \\
\text { space }\end{array}$ \\
\hline $\begin{array}{l}\text { Entrepreneurial } \\
\text { Bucharest } \\
\text { Mentoring for } \\
\text { entrepreneurs }\end{array}$ & $\begin{array}{l}\text { BCR Hopes } \\
\text { supports children with } \\
\text { musical talent }\end{array}$ & $\begin{array}{l}\text { Scoala9 (New School) } \\
\text { Supports education in local } \\
\text { communities }\end{array}$ & $\begin{array}{l}\text { Sponsorship of over } 50 \\
\text { reading and science } \\
\text { centers in kindergartens in } \\
\text { poor rural communities }\end{array}$ & $\begin{array}{l}\text { Startarium, town of the } \\
\text { entrepreneurs } \\
\text { supports entrepreneurial } \\
\text { education, testing ideas } \\
\text { and financing }\end{array}$ \\
\hline \multirow[t]{2}{*}{$\begin{array}{l}\text { I want to be entrepreneur } \\
\text { young people learn } \\
\text { directly from } \\
\text { entrepreneurs (together } \\
\text { with Romanian Business } \\
\text { Leaders Foundation) }\end{array}$} & $\begin{array}{l}\text { "Second chance" } \\
\text { reintegration of children } \\
\text { from disadvantaged } \\
\text { backgrounds in schools } \\
\text { and society (with Salvați } \\
\text { Copiii România) }\end{array}$ & $\begin{array}{l}\text { MINDCRAFT } \\
\text { hubs, start-ups, robotics } \\
\text { teams and incubators for } \\
\text { developing the young } \\
\text { generation }\end{array}$ & $\begin{array}{l}\text { Ourselves, My Family, My } \\
\text { Town, My Community, } \\
\text { Our Economy, Bank } \\
\text { Alphabet } \\
\text { financial educationfor } \\
\text { children inschools and } \\
\text { secondary schools }\end{array}$ & $\begin{array}{l}\text { Concordia Bakery } \\
\text { developing social } \\
\text { entrepreneurshipfor } \\
\text { professional integration } \\
\text { of the young }\end{array}$ \\
\hline & $\begin{array}{l}\text { Donate a book } \\
\text { internal book donation } \\
\text { campaign for schools in } \\
\text { disadvantaged } \\
\text { communities }\end{array}$ & $\begin{array}{l}\text { Superpeople for } \\
\text { superchances } \\
\text { internal salary donation } \\
\text { program. The donated } \\
\text { amounts are then doubled } \\
\text { by the bank. }\end{array}$ & & $\begin{array}{l}\text { Manifesto } \\
\text { Educational project for } \\
\text { high school students in } \\
\text { partnership with Oricum } \\
\text { (Anyway) Association }\end{array}$ \\
\hline $\begin{array}{l}\text { Supporting the Romanian } \\
\text { Basketball Federation, the } \\
\text { nationalteams and the } \\
\text { basketball academy }\end{array}$ & $\begin{array}{l}\text { START! } \\
\text { Business } \\
\text { Entrepreneurial education } \\
\text { (with Junior Achievement) }\end{array}$ & $\begin{array}{l}\text { Support of the Romanian } \\
\text { Handball Federation and } \\
\text { the WTA BRD Bucharest } \\
\text { Open }\end{array}$ & & $\begin{array}{l}\text { Come to school! } \\
\text { reducing school abandon } \\
\text { (with UNICEF) }\end{array}$ \\
\hline $\begin{array}{l}\text { Supporting the production } \\
\text { of the documentary Maria } \\
\text { - Inima României }\end{array}$ & $\begin{array}{l}\text { Caravan of the social } \\
\text { business } \\
\text { Promoting the cocial } \\
\text { entrepreneurial initiative }\end{array}$ & & & \\
\hline $\begin{array}{l}\text { Supporting a symbolic } \\
\text { event for the Romanian } \\
\text { community in Italy. the } \\
\text { lighting in colors of } \\
\text { Romania of Trajan's } \\
\text { Column, in Rome. }\end{array}$ & $\begin{array}{l}\text { Food bank } \\
\text { collection and distribution } \\
\text { of perishable food to low- } \\
\text { income people (with the } \\
\text { Red Cross Ro) }\end{array}$ & & & \\
\hline
\end{tabular}

